\title{
Temperatures Variation in Different Human Tissues according to Blood Flow Coefficient
}

\author{
Y. E. Mohammed Ali \\ Department of EE \\ Mosul University \\ College of Engineering
}

\author{
A. G. Saber \\ Department of EE \\ Mosul University \\ College of Engineering
}

\begin{abstract}
This paper presents different data represented with specific absorption rate (SAR) and temperature deviation, which obtained by using phantom models of different tissues represented using numerical simulation CST Studio Suite which uses two problem, high frequency problem for evaluating electric field and (SAR), and Thermal Steady State (TSS) problem for evaluating temperature and activating others heat sources. This paper also present classifications for tissues according to ability to energy absorption and heat dissipation. First classification, tissues with low blood flow and high water content, the tissue will absorb the energy (SAR) and cause temperature increasing. Second classification, tissues with low blood flow and low water content, the tissue will absorb some of the energy (SAR) and causing temperature increasing with low energy dissipation. Third classification, tissues with high blood flow and high water content, the tissue will absorb the energy (SAR) and cause minor temperature increasing because of high blood flow.
\end{abstract}

\section{Keywords}

Electric field; Water content; Human tissue; Blood flow; CST; SAR; TSS;

\section{INTRODUCTION}

The recent researches and reports focus on estimation the specific absorption rate (SAR) and the temperatures deviation, Some studies and scientific reports recorded occurrences of some cases of headaches and other cases recorded occurrences of eye diseases due to heat generated by exposure to high levels of radiation energy[1]. Generally human tissue divided into multilayer and each layer represents tissue[2,3,4]. The electromagnetic properties of human tissues vary with frequency changing $[5,6,7]$. each tissue had different thermal properties[8,9]. This paper gives interesting for evaluating the maximum specific absorption rate (SAR) inside different tissues and estimating the maximum temperatures. This study focused on radiated power amount $600 \mathrm{~mW}$ emitted from dipole antenna with frequency $915 \mathrm{MHz}$ located at distance $20 \mathrm{~mm}$ from phantom model of human tissue with size $(60 \times 60 \times 60) \mathrm{mm}$. This frequency consider one of ISM (Industrial Scientific and Medical) bands which commonly used in the diagnostic and therapeutic applications. ISM bands were originally reserved internationally for the use of RF electromagnetic fields for industrial, scientific and medical purposes other than communications $[10,11,12,13]$. The main purpose of the recent researches is estimating the temperatures deviation in the tissues. But for evaluate temperatures deviation at certain depth we need to find (SAR) at certain frequency by applying equation (1) [14],
CST C95.3 averaging method is used and it's similar to IEEE C95.3 [15,16]. The Institute of Electrical and Electronics Engineers (IEEE C95.1) and International Commission on NonIonizing Radiation (ICNIRP) are issued basic restriction limits of SAR [17,18].

$S A R=\frac{\sigma E^{2}}{\rho}(W / K g)$

where $\sigma$ represents the conductivity of tissue $(\mathrm{S} / \mathrm{m}), \rho$ the density of the tissue $\left(\mathrm{kg} / \mathrm{m}^{3}\right)$ and $\mathrm{E}$ the electric field $(\mathrm{V} / \mathrm{m})$. The temperature can be obtained by applying Bio-heat equation(2)[19].

$C_{p} \frac{\partial T}{\partial t}=\nabla \cdot(k \nabla T)+\rho(S A R)-B_{f}\left(T_{\text {tissue }}-T_{b}\right)+A_{o}$

Where $C_{p}$ represent specific heat of tissue, $K$ the thermal conductivity of the tissue, $\mathrm{T}_{\text {tissue }}$ the temperature of the tissue, $\mathrm{T}_{\mathrm{b}}$ the temperature of the blood, $\mathrm{A}_{0}$ the metabolic heat generation, $B_{f}$ the term associated with blood perfusion. The most important applications for evaluating temperatures deviation are[8,20].

- Medical applications, such as hyperthermia and electrosurgical Units.

- Studying the generated heat by exposure to Electromagnetic waves which penetrate the tissues.

The CST software is used for evaluating the electric field and SAR inside human tissue in high frequency problem, then the temperature is evaluating using thermal steady state (TSS) problem [21]. The preliminary temperatures in the thermal stationary state (TSS) are achieved with rms power scaling factors by multiplying input power by two[21]. The CST software applies FIT technique (Finite Integration Technique)[21]. This paper gives interesting for evaluating maximum SAR for $1 \mathrm{~g}$ and maximum SAR for $10 \mathrm{~g}$ as well as maximum temperature deviation for ten tissues.

\section{CHARACTERISTICS OF HUMAN TISSUES}

\subsection{Electromagnetic Properties}

The Biological tissues instituted the body are comprised mostly of water, the water institutes $72 \%$ of human tissues[22]. Generally, $99 \%$ of the tissue are made of four major elements; oxygen, hydrogen, nitrogen and carbon[22], The recent and previous research show that the electrical properties of human 
tissue are changing with frequency[5,6,7]. The electrical properties of human tissue include both of conductivity and permittivity. The database of most parameter are available [6,7]. Table 1, includes information for several tissues at frequency $915 \mathrm{MHz}$ [6], as well as approximate percentage of water content for each tissue[23]. The electrical properties are important for evaluating E-field and SAR using.

Table 1. Electric Properties of Human Tissue at 915MHz[5]

\begin{tabular}{|c|c|c|c|}
\hline Tissue & Water content $\%$ & $\begin{array}{c}\text { Conductivity } \\
\sigma(\mathrm{S} / \mathrm{m})\end{array}$ & $\begin{array}{c}\text { Permittivity } \\
\mathrm{R} \varepsilon\end{array}$ \\
\hline Muscle & $73-78$ & 0.948 & 54.99 \\
\hline Fat & $5-20$ & 0.051 & 5.459 \\
\hline Brain(White) & $68-78$ & 0.595 & 38.83 \\
\hline Brain(Gray) & $82-85$ & 0.948 & 52.65 \\
\hline Spleen & $76-81$ & 1.280 & 57.07 \\
\hline Lung & $80-83$ & 0.459 & 21.97 \\
\hline Liver & $73-77$ & 0.861 & 46.76 \\
\hline Kidney & $78-79$ & 1.400 & 58.55 \\
\hline Bone & $44-45$ & 0.145 & 12.44 \\
\hline Eye-Sclera & $65-83$ & 1.172 & 55.23 \\
\hline
\end{tabular}

\subsection{Thermal Properties}

The bio-thermal and bio-heat properties of tissues are fixed in most recent researches $[19,20]$, the important parameters for simulation bio-thermal properties are thermal conductivity, heat capacity, blood flow coefficient, basal metabolic rate and density. The temperature deviation is predicted by using Bioheat equation which mention as equation (2). Table 2, content the thermal properties which most used in simulation the tissues[19]. The blood flow coefficient represents the scattered energy caused by flowing the blood through tissue, the basal metabolic rate represents the generating energy caused by metabolic processes[24].

Table 2. Thermal properties of human tissue [19]

\begin{tabular}{|c|c|c|c|c|c|}
\hline 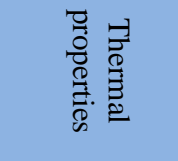 & \multirow{2}{*}{ 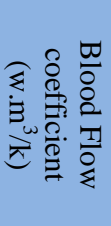 } & \multirow[t]{2}{*}{ 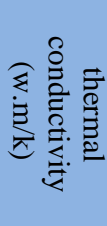 } & \multirow{2}{*}{ 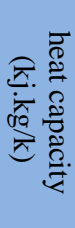 } & \multirow{2}{*}{ 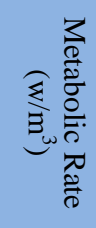 } & \multirow{2}{*}{ 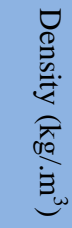 } \\
\hline Tissue & & & & & \\
\hline Muscle & 2700 & 0.46 & 3.6 & 480 & 1047 \\
\hline Fat & 1700 & 0.201 & 2.5 & 300 & 916 \\
\hline Brain(White) & 17280 & 0.502 & 3.6 & 7100 & 1030 \\
\hline Brain(Gray) & 40000 & 0.502 & 3.7 & 7100 & 1030 \\
\hline Spleen & 82000 & 0.543 & 3.7 & 15000 & 1020 \\
\hline Lung & 9500 & 0.624 & 3.6 & 1700 & 1020 \\
\hline
\end{tabular}

\begin{tabular}{|c|c|c|c|c|c|}
\hline Liver & 68000 & 0.469 & 3.6 & 12000 & 1020 \\
\hline Kidney & 270000 & 0.499 & 3.9 & 48000 & 1020 \\
\hline Bone & 3400 & 0.41 & 1.3 & 610 & 1990 \\
\hline Eye-Sclera & 10300 & 0.624 & 4.17 & 14250 & 1010 \\
\hline Air & 0 & 0.024 & 1.01 & 0 & 1.292 \\
\hline
\end{tabular}

\section{SIMULATION THE TISSUES AND} ANTENNA

In order to simulate tissues according to live organs, electric and thermal properties according to Table 1 and Table 2 are used for simulating phantom model with size $(60 \times 60 \times 60) \mathrm{mm}$ in CST software coordinates. A dipole antenna with parameter of wire length, $\mathrm{L}=0.47 \lambda \mathrm{mm}$, wire radius, $\mathrm{r}=1.5 \mathrm{~mm}$, and feed gap, $\mathrm{fg}$ $=2 \mathrm{~mm}$ was located at distance $20 \mathrm{~mm}$ from the phantom model as shown in Figure 1.

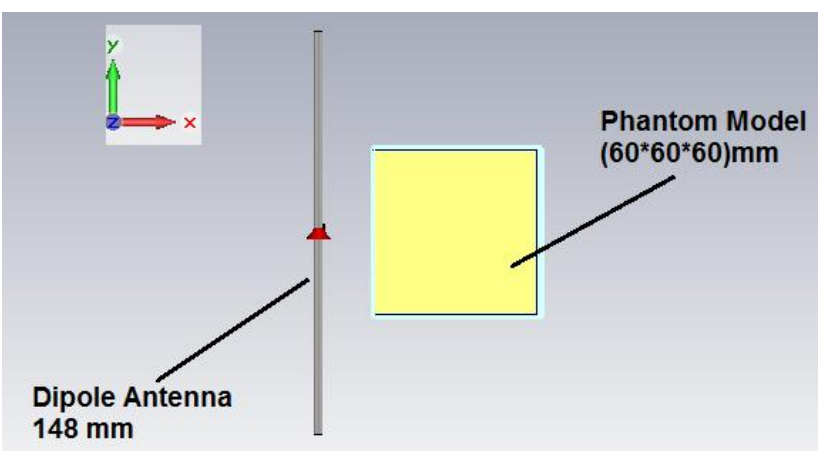

Fig 1: The simulation of dipole antenna and phantom model of tissue.

The return loss of dipole antenna shown in Figure 2, which work at $915 \mathrm{MHz}$.

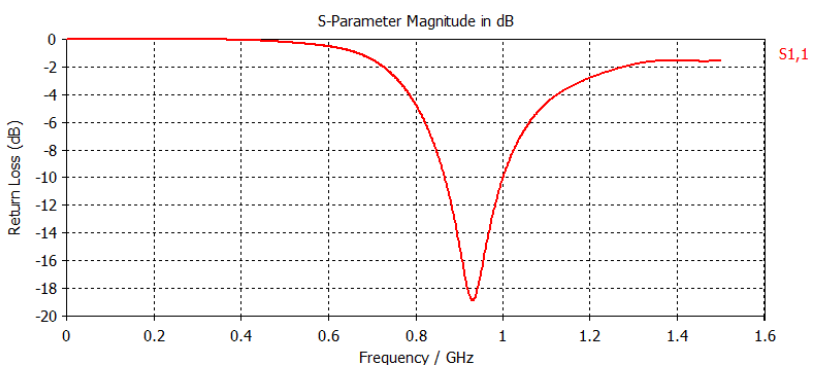

Fig 2: The return loss (RL) of dipole antenna.

\section{RESULTS AND COMPAROSON}

The tissues will classify according to water content and blood flow, from Table 1 we can observed some tissue have low water content and low blood flow coefficient from Table 2 such as fat tissue and bone tissue. The decrease in the value of the water content leads to a decrease in the values of the conductivity, therefore, the values of the specific absorption rate are expected to decrease. Figure 3 shows the values of $\mathrm{SAR}_{1 \mathrm{~g}}$ and $\mathrm{SAR}_{10 \mathrm{~g}}$ was drawing as a function of phantom depth on coordinate $(\mathrm{x}, 0,0)$ of CST microwave studio. 


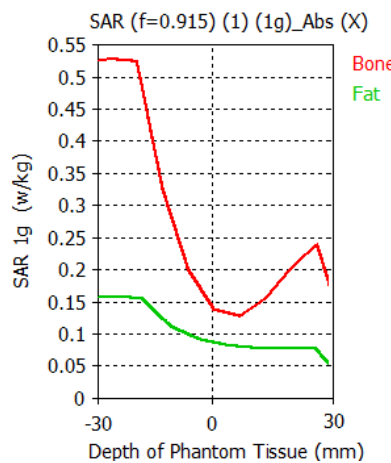

(a):SAR (1g)

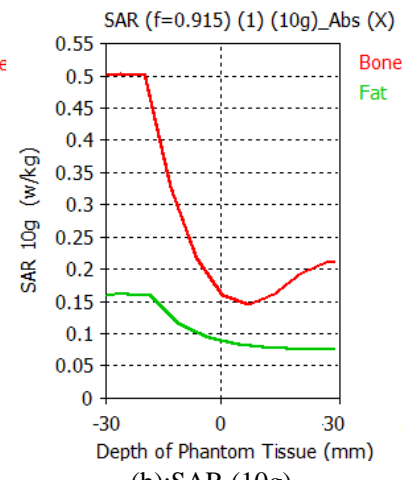

(b):SAR (10g)
Fig 3:. Distribution of SAR inside phantom for bone and fat tissue.

The tissues; spleen, kidney and liver which have high water content and high blood flow coefficient, therefore the conductivity will increase and the values of the specific absorption rate are expected to increase. Figure 4 shows the value of $\mathrm{SAR}_{1 \mathrm{~g}}$ and $\mathrm{SAR}_{10 \mathrm{~g}}$ for different tissues.

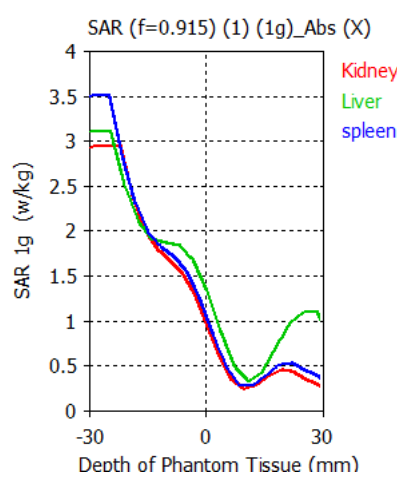

(a):SAR $(1 \mathrm{~g})$

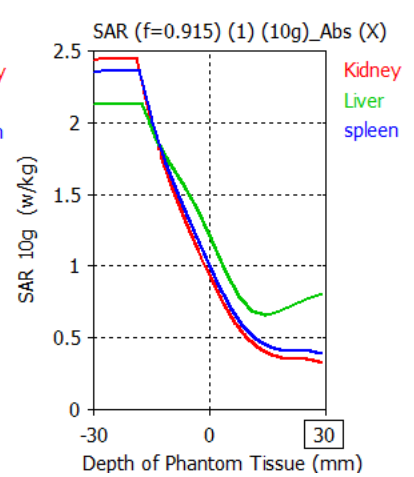

(b):SAR (10g)
Fig 4: Distribution of SAR inside phantom for kidney, spleen and liver tissues.

The tissues; muscle, lung and eye which have high water content and low blood flow coefficient, therefore the conductivity will increase and the values of the specific absorption rate are expected to increase. Figure 5 shows the value of $\mathrm{SAR}_{1 \mathrm{~g}}$ and $\mathrm{SAR}_{10 \mathrm{~g}}$ for different tissues.

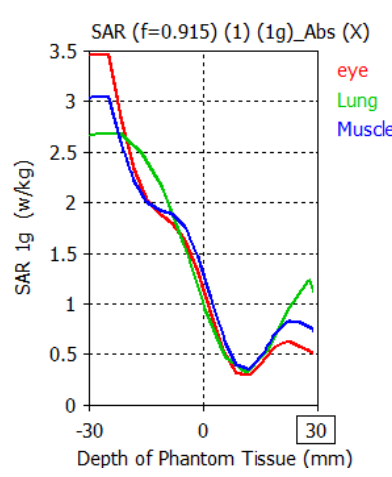

(a):SAR (1g)

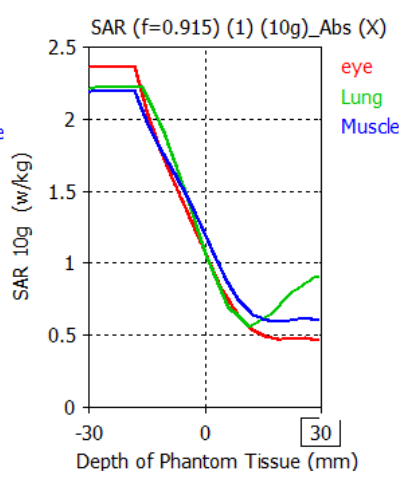

(b):SAR (10g)
Fig 5: Distribution of SAR inside phantom for eye, lung and muscle.
The tissue of brain divided to white substance and gray substance, the values of $\mathrm{SAR}_{1 \mathrm{~g}}$ and $\mathrm{SAR}_{10 \mathrm{~g}}$ for brain shown in Figure 6.

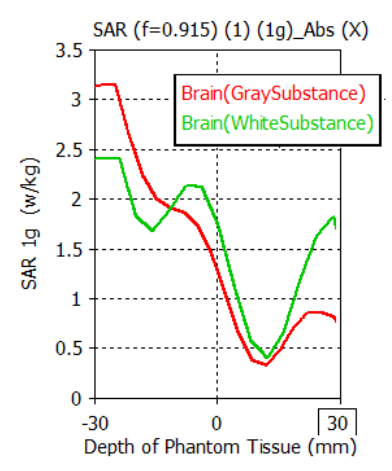

(a):SAR (1g)

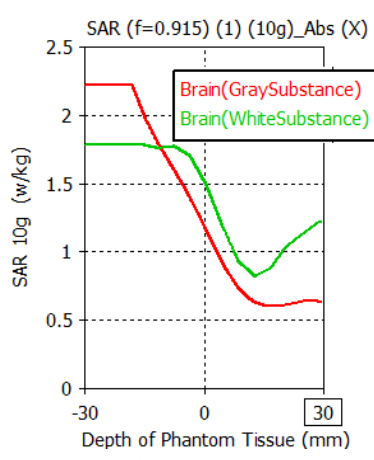

(b):SAR (10g)
Fig 6: Distribution of SAR inside phantom for brain tissues.

For evaluating the temperature deviation $(\Delta T=$ Max Temp $T_{\circ}$ ) we should record the initial temperature $\left(T_{\circ}\right)$, which obtained by turn off the power on antenna and record the temperature, the maximum temperature can be obtained by applying $600 \mathrm{~mW}$ to dipole antenna and record maximum temperature inside tissue. Table 3 explain comparison for a ten tissue which used for testing, the comparison in Table 3 contain $\max \mathrm{SAR}_{1 \mathrm{~g}}$, max $\mathrm{SAR}_{10 \mathrm{~g}}$, initial temperature, maximum temperature and temperature deviation inside tissues.

Table 3. Values of $\mathrm{SAR}_{1 \mathrm{~g}}, \mathrm{SAR}_{10 \mathrm{~g}}$, temperature and temperature deviation for different tissues.

\begin{tabular}{|c|c|c|c|c|c|}
\hline Tissue & 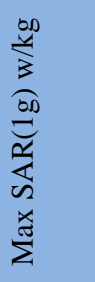 & 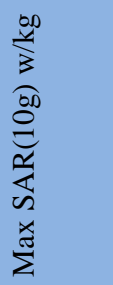 & 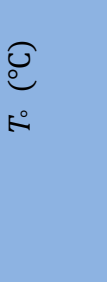 & 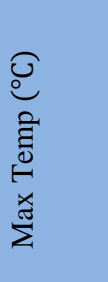 & ヶ \\
\hline Muscle & 3.045 & 2.193 & 36.98 & 37.40 & 0.42 \\
\hline Fat & 0.191 & 0.179 & 36.96 & 37.02 & 0.06 \\
\hline $\begin{array}{c}\text { Brain } \\
\text { (White) }\end{array}$ & 2.407 & 1.784 & 37.40 & 37.51 & 0.11 \\
\hline $\begin{array}{l}\text { Brain } \\
\text { (Gray) }\end{array}$ & 3.145 & 2.222 & 37.17 & 37.23 & 0.06 \\
\hline Spleen & 3.510 & 2.357 & 37.18 & 37.21 & 0.03 \\
\hline Lung & 2.679 & 2.221 & 37.15 & 37.32 & 0.17 \\
\hline Liver & 3.112 & 2.132 & 37.17 & 37.21 & 0.04 \\
\hline
\end{tabular}




\begin{tabular}{|c|c|r|r|r|r|}
\hline Kidney & 2.942 & 2.443 & 37.17 & 37.18 & 0.01 \\
\hline Bone & 0.527 & 0.502 & 37.07 & 37.17 & 0.1 \\
\hline $\begin{array}{c}\text { Eye- } \\
\text { Sclera }\end{array}$ & 3.464 & 2.362 & 38.36 & 38.51 & 0.15 \\
\hline
\end{tabular}

\section{CONCLUSIONS}

The results which obtained from testing ten tissues appeared there three classification of tissues, by comparison the results in Table 3 with the parameter of tissues in Table 1 and Table 2, first classification some tissues recorded maximum temperature deviation, which was ranging 0.16 to 0.4 such as eye, lung and muscle, because those tissues had high water content and high conductivity this caused increasing in SAR, the Max SAR $_{1 \mathrm{~g}}$ recorded was $3.464 \mathrm{w} / \mathrm{kg}$, the low blood flow coefficient is causing accumulation of energy with low heat dissipation. The second classification recorded minor temperature deviation which is ranging 0.06 to 0.1 such as fat and bone, although the low water content and SAR, the Max $\mathrm{SAR}_{1 \mathrm{~g}}$ recorded was 0.527 $\mathrm{w} / \mathrm{kg}$, the very low blood flow coefficient caused accumulation of energy with very low heat dissipation. Third classification some tissue such as spleen, liver and kidney recorded very low temperature deviation which was ranging 0.01 to 0.04 , because these tissues have very high blood flow coefficient, this caused high heat dissipation, although high water content which caused high SAR, the Max SAR $1 \mathrm{~g}$ recorded was $3.51 \mathrm{w} / \mathrm{kg}$, but because the high blood flow coefficient which regarded as natural heat sink caused very low temperature deviation.

\section{REFERENCES}

[1] S. I. AL-Mously, "computation of temperature rise in the human head Due to Different Mobile Phone Models," IEEE Microwave Symposium (MMS), Guzelyurt, Cyprus, pp. 370-373, 2010.

[2] M. Ken, G. P. Moll and other, "Data-Driven Physics for Human Soft Tissue Animation, " ACM Transactions on Graphics, Vol. 36, No. 4, pp. 1-12, July 2017.

[3] G. Varotto and E. M. Staderini, "A 2D Simple Attenuation Model for EM Waves in Human Tissues: Comparison with a FDTD 3D Simu-lator for UWB Medical Radar," IEEE International Conference on Ultra-Wide Band., Vol. 3, 2008.

[4] N. Vidal and J. M. L'opez, "Changes in Electromagnetic Field Absorption in the Presence of Subcutaneous Implanted Devices: Minimizing Increases in Absorption," IEEE Trans. Electromag. Compat., Vol. 52, No. 3, August. 2010.

[5] S. Gabriel, R. U. Lau and C. Gabriel, "The Dielectric Properties of Biological Tissues:II. Measurement in The Frequency Range $10 \mathrm{~Hz}$ to $20 \mathrm{GHz}$," Phys. Med. Biol., Vol. 41, pp. 2251 - 2269, 1996.

[6] N. Carrara. Dielectric properties of body tissues. IFAC, Institute for applied physics, Italy . ( 2007). [Online]. Available: http://niremf.ifac.cnr.it/tissprop/

[7] Federal Communications Commission. Tissue dielectric properties. FCC, Washington, DC. (2008). [Online]. Available:

http://www.fcc.gov/fcc-bin/dielec.sh

[8] S. Curto, T. S. P. See, P. Evoy, M. J. Ammann and Z. N. Chen, "In-silico Hyperthermia Performance of a Near-Field Patch Antenna at Various Positions on a Human Body Model ," IET Microwave, Antenna and Propagation, Vol. 5, Issue: 12, pp. 1408-1415, 2011.

[9] T. Wessapan and P. Rattanadecho, "Temperature induced in the testicular and related tissues due to electromagnetic fields exposure at $900 \mathrm{MHz}$ and 1800 $\mathrm{MHz}$, " International Journal of Heat and Mass Transfer, Vol. 102, pp. 1130-1140, July 2016.

[10] Communication Systems (MICS) Operating in the Mobile Service in the Frequency Band 401-406 MHz, ITU-R SA.1346, Int. Telecommu-nications Union, 1998.

[11] FCC Rules and Regulations, Subpart E and I, Part 95, Federal Comm-unications Commission, Nov. 2002.

[12] Relating to the Use of Short Range Devices (SRD), ERC Recomm-endation 70-03, European Radiocommunications Committee, Apr. 2002.

[13] Radiocommunications Agency, "UK radio interface requirement 2030 short range devices," ver. 1.2, Oct. 2002.

[14] S. W. Park, K, Wake, S. Watanable, " Calculation Errors of the Electric Field Inducedin a Human Body Under Quasi-Static Approximation Conditions," IEEE Transactions on Microwave Theory and Techniques., Vol. 61, No. 5, pp. 2153 - 2160, 2013.

[15] Y. R. Club and B. branch, "Human Health Effects from Radiofrequency and Microwave Fields," Journal of Basic and Applied Scientific Research,Vol. 2, pp. 12302-12305, 2012.

[16] T. Samaras, A. Christ, A. Klingenböck, and Niels Kuster, "Worst Case Temperature Rise in a OneDimensional Tissue Model Exposed to Radiofrequency Radiation," IEEE Transactions on Biomedical Engineering, Vol. 54, No. 3, pp. 492-496, March 2007.

[17] M. A. Bennet, J. S. Poomathi, C. Kalpana. and S. S. Priya, "Specific Aborption Rare Assessment on Human Head due to Radiation by Mobile Phone Antenna, " International Journal on Smart Sensing and Intelegint System, pp. 374-394, septumber 2017.

[18] Y.Wu, M.D. Nieuwenhoff, F.J.P.M. Huygen, F.C.T van der Helm, S. Niehof and A.C. Schouten, "Characterizing human skin blood flow regulation in response to different local skin temperature perturbations, " Microvascular Research., Vol. 111, pp. 96-102, 2017. 
[19] A. Hirata, O. Fujiwara and T. Shiozawa, "Correlation Between Peak Spatial-Average SAR and Temperature Increase Due to Antennas Attached to Human Trunk," IEEE Transactions on Biomedical Engineering, Vol. 53, No. 8, pp. 1658-1664, August 2006.

[20] O. Szasz, G. Szigeti and A. Szasz, "Connections between the Specific Absorption Rate and the Local Temperature," Open Journal of Biophysics, Vol. 6, pp. 53-74, July 2016.

[21] T. Tuovinen, M. Berg, K. Y. Yazdandoost, M. Hämäläinen and J. Iinatti, "On the Evaluation of Biological Effects of Wearable Antennas on Contact with Dispersive Medium in Terms of SAR and BioHeat by Using FIT Technique," 7th International Symposium on Medical Information and
Communication Technology (ISMICT), Tokyo, Japan, pp. 149-153, 2013.

[22] Q. Klemetsen, "Design and Evaluation of a Medical Microwave Radiometer for Observing Temperature Gradients Subcutaneously in the Human Body," Ph.D. Thesis, Faculty of Science Department of Physics and Technology, University of Tromso, Tromso, Norway, 2012.

[23] R. Pethig, "Dielectric Properties of Biological Materials," IEEE Transactions on Electrical Insulation, Vol. EI-19, No.5, Oct. 1984.

[24] E. D. Yildirim, "Mathematical model of the human thermal system," M.Sc. Thesis, Izmir Institute of Technology, Izmir, Turkey, January 2005. 